\title{
PENGARUH MODEL PEMBELAJARAN BERBASIS MASALAH BERBANTUAN MOBILE POCKET BOOK FISIKA TERHADAP KEMAMPUAN PEMECAHAN MASALAH PESERTA DIDIK
}

\author{
Rindayu Noviatika*, Gunawan, Joni Rokhmat \\ Program Studi Pendidikan Fisika, Universitas Mataram \\ *Email: rindayunoviatika@gmail.com
}

DOI: http://dx.doi.org/10.29303/jpft.v5i2.1163

\begin{abstract}
This study aims to determine the effect of problem-based learning models assisted by pocket book physics on problem-solving abilities. The type of research used was quasi-experimental design with pretest-posttest control group design. The population in this study were all students of class $X$ MIPA Senior High School in Mataram. The research sample was taken using cluster random sampling technique, so that the selected students of class X MIPA five were 31 people as the experimental class and the X class MIPA six as many as 27 people as the control class. The experimental class was treated in the form of a problem-based learning model assisted by pocket book physics mobile and the control class was treated in the form of conventional learning. The instrument used to measure problem solving ability is a test instrument in the form of a descriptive test of five items. The research hypothesis was tested using the t-test with a significance level of 5\%. The t-test produces a t-count value of problem solving ability of 5.832 which is smaller than $t_{\text {table }}$ which is equal to 2.003 so that $H_{0}$ is rejected and $H_{a}$ is accepted. So it can be concluded that there is the influence of the problem-based learning model assisted by pocket book physics on students' problem solving abilities. This result can be proven by the $\mathrm{N}$-gain test, where there is an increase in problem solving abilities of $60 \%$ for the experimental class and the control class by $34 \%$ with the medium category.
\end{abstract}

Keywords: Problem Based Learning; Mobile Pocket Book of Physic; Problem Solving

\section{PENDAHULUAN}

Ilmu Pengetahuan dan Teknologi (IPTEK) dari masa ke masa berkembang sangat pesat. Perkembangan abad ke-21 menuntut peserta didik untuk memiliki beberapa keterampilan, yaitu kreativitas serta inovasi (creativity and innovation), berpikir kritis (critical thinking), pengambilan keputusan (decision making), metakognisi, dan pemecahan masalah (problem solving) (Global Cities Education Network Report, 2012).

Kemampuan pemecahan masalah merupakan dasar yang diperlukan peserta didik untuk menyelesaikan berbagai persoalan yang diberikan oleh guru, terutama persoalan yang berhubungan dengan fisika. Fisika sebagai bagian dari sains tidak dapat dipisahkan dari keterampilan proses untuk memecahkan fenomena yang ada di alam. Oleh karena itu, kemampuan pemecahan masalah perlu untuk ditumbuh-kembangkan dalam diri peserta didik karena suatu permasalahan tidak dapat diselesaikan secara langsung tanpa mengetahui penyebabnya terlebih dahulu.

Rokhmat (2013) mengungkapkan bahwa kemampuan pemecahan masalah merupakan kemampuan peserta didik untuk menggunakan pengetahuan yang dimilikinya dalam memilih atau memprediksi secara deduktif berbagai kemungkinan akibat-akibat dari suatu fenomena. Kemampuan pemecahan masalah sendiri merupakan bagian dari pembelajaran yang sangat penting karena dalam proses pembelajaran maupun penyelesaiannya, peserta didik dimungkinkan untuk memperoleh pengalaman menggunakan pengetahuan yang sudah dimiliki (Abdani $e t$ $a l$, 2018). Selain itu Tamami et al, (2017) mengungkapkan bahwa kemampuan pemecahan masalah masih menjadi kendala yang dihadapi oleh kebanyakan peserta didik, kurangnya kemampuan pemecahan 
masalah ini patut diduga disebabkan oleh kurangnya pemahaman peserta didik akan konsep-konsep yang berhubungan dengan fisika.

Seng (2009) di dalam bukunya mengungkapkan bahwa, suatu masalah akan memicu terjadinya motivasi emosional dan berpikir mendalam. Artinya setiap masalah yang ada akan memicu seseorang untuk memikirkan solusi dari permasalahan tersebut bagaimanapun caranya. Sehingga Gunawan (2017) menyatakan bahwa masalah yang muncul dalam proses pembelajaran akan berdampak buruk bagi hasil belajar peserta didik dan peserta didik menjadi kurang memahami konsep atau materi dengan baik sehingga menyebabkan rendahnya kemampuan pemecahan masalah terhadap materi tersebut.

Hasil tes yang dilakukan oleh peneliti di SMAN 2 Mataram untuk mengetahui kemampuan pemecahan masalah peserta didik masih tergolong rendah. Kurangnya kemampuan pemecahan masalah peserta didik ini patut diduga disebabkan oleh pemahaman peserta didik akan konsep-konsep fisika yang masih kurang. Guru hanya menekankan pembelajaran yang memungkinkan peserta didik memiliki kemampuan hanya sebatas menjawab soal saja tanpa memahami materi tersebut. Masalah ini akan membawa pola pikir peserta didik pada pembelajaran fisika menjadi kurang menarik sehingga banyak peserta didik yang tidak menyukai pembelajaran fisika. Padahal, pembelajaran fisika menjadi lebih menarik jika guru dapat membuat peserta didik terlibat secara aktif untuk berpikir secara terbuka. Sehingga Rokhmat et al, (2012) menyatakan bahwa pembiasaan berpikir secara terbuka dapat memfasilitasi peserta didik untuk memahami konsep fisika secara utuh.

Kemampuan pemecahan masalah peserta didik dapat dilatih saat proses belajar mengajar berlangsung, dengan menggunakan model pembelajaran yang tepat dapat melatih peserta didik dari segi pengetahuan, sikap, dan keterampilan sehingga peserta didik dapat lebih mudah memahami materi. Solusi alternatif yang ditawarkan peneliti adalah dengan menggunakan model pembelajaran berbasis masalah. Model pembelajaran berbasis masalah merupakan salah satu model pembelajaran inovatif yang dapat memberikan kondisi belajar aktif kepada peserta didik (Ngalimun, 2014). Menurut Aziz et al, (2017), model pembelajaran berbasis masalah merupakan model pembelajaran yang menyediakan pengalaman autentik yang mendorong peserta didik untuk belajar aktif, mengkonstruksi pengetahuan, dan mengintegrasikan konteks belajar di sekolah dan belajar di kehidupan nyata secara alamiah sebagai rangkaian aktifitas pembelajaran yang menekankan pada proses penyelesaian secara alamiah. Sedangkan menurut Niami et al, (2018) model pembelajaran berbasis masalah merupakan model pembelajaran yang menekankan penyajian masalah sebagai titik tolak untuk memperoleh pengetahuan baru dengan mencari solusi secara kolaboratif.

Pembelajaran yang cenderung kurang menarik dengan fasilitas yang kurang memadai juga diduga dapat menjadi penghambat peserta didik dalam mengembangkan kemampuan pemecahan masalahnya. Salah satu fasilitas yang sangat penting pada proses pembelajaran adalah keberadaan buku. Buku cetak atau buku teks merupakan media pembelajaran yang digunakan sebagai pendamping bagi media pembelajaran lainnya. Landau et al, (2011) dalam penelitiannya menunjukkan bahwa salah satu komponen yang perlu diperhatikan dalam pembelajaran fisika adalah ketersediaan buku pembelajaran. Namun keberadaan buku masih kurang menarik perhatian peserta didik untuk 
membacanya. Hal tersebut dikarenakan buku cetak tidak dapat menampilkan animasi, video, dan audio sehingga peserta didik cenderung merasa bosan dan tidak dapat memahami materi yang bersifat abstrak.

Perkembangan teknologi yang terjadi juga harus dimanfaatkan untuk memaksimalkan proses pembelajaran, salah satunya dengan memanfaatkan media pembelajaran. Penggunaan media dalam proses pembelajaran dapat mempermudah menjelaskan materi-materi yang abstrak dan sulit dipahami oleh peserta didik. Selain itu, penggunaan media dapat mengurangi rasa bosan peserta didik dalam mengikuti proses pembelajaran karena media tidak hanya menyajikan informasi dalam bentuk teks namun juga dapat menyajikan suatu materi dalam bentuk lain yang lebih menarik.

Teknologi informasi dan komunikasi (TIK) saat ini telah digunakan pada berbagai aspek kehidupan manusia termasuk di sekolah. Penggunaan smartphone di kalangan pelajar dapat dimanfaatkan dalam bidang pendidikan salah satunya yaitu dengan menggunakan media pembelajaran berupa buku digital. Dengan menggunakan buku saku (pocket book) digital yang terunduh di smartphone masing-masing peserta didik diharapkan dapat menarik minat untuk membaca materi yang disajikan dalam buku digital tersebut.

Embong et al, (2012) menyatakan bahwa buku digital dapat memberikan banyak manfaat karena informasi dapat disajikan melalui multimedia yaitu berupa narasi, animasi, video, audio. Selain itu Khumaidi (2018) dalam penelitiannya menggunakan mobile pocket book fisika untuk mengukur hasil belajar peserta didik juga menunjukkan bahwa buku saku digital dinilai dapat memudahkan peserta didik untuk belajar karena memiliki keunggulankeunggulan seperti berbentuk digital yang dapat memudahkan peserta didik untuk mengaksesnya dimana saja, tidak mudah rusak karena tidak dalam bentuk cetakan tetapi dalam bentuk software, menghemat tempat karena tidak membutuhkan ruang penyimpanan. Namun penggunaan buku digital tidak dapat menggantikan peran buku cetak atau buku teks, hanya saja buku digital dapat dijadikan sebagai alternatif pemilihan media dalam pembelajaran.

Dengan adanya permasalahanpermasalahan tersebut diperlukan inovasi guru dalam menyampaikan materi selama proses pembelajaran, misalnya dengan menggunakan media pembelajaran yang berbeda, yaitu dengan menggunakan media pembelajaran mobile pocket book fisika berbasis android. Penelitian ini bertujuan untuk mengetahui pengaruh model pembelajaran berbasis masalah berbantuan mobile pocket book fisika terhadap kemampuan pemecahan masalah peserta didik.

\section{METODE PENELITIAN}

Penelitian ini termasuk penelitian quasi experimental dengan desain pretest posttest control group. Populasi penelitian ini adalah seluruh peserta didik kelas $\mathrm{X}$ MIPA pada salah satu SMA Negeri di Mataram dengan teknik pengambilan sampel menggunakan cluster random sampling, sehingga diperoleh $\mathrm{X}$ MIPA 5 yang berjumlah 31 peserta didik sebagai kelas eksperimen dan X MIPA 6 yang berjumlah 27 peserta didik sebagai kelas kontrol.

Variabel dalam penelitian ini terdiri dari variabel bebas yaitu model pembelajaran berbasis masalah berbantuan mobile pocket book fisika, variabel terikat yaitu berupa kemampuan pemecahan masalah, dan variabel kontrol yaitu materi ajar, guru yang mengajar, dan alokasi waktu pembelajaran. Instrumen yang digunakan adalah tes kemampuan pemecahan masalah. Teknik pengumpulan data berupa tes tertulis 
berbentuk soal uraian yang berjumlah 5 soal. Indikator pemecahan masalah (IPM) yang digunakan dalam tes ini terdiri dari enam indikator yaitu sebagai berikut: IPM-1 pemahaman (understanding), IPM-2 pemilihan (selecting), IPM-3 pembedaan (differentiating), IPM-4 penentuan (determining), IPM-5 penerapan (applying), dan IPM-6 pengidentifikasian (identifying).

Instrumen tes kemampuan pemecahan masalah sebelum digunakan dalam penelitian harus memenuhi beberapa syarat yaitu uji validitas, reliabilitas, tingkat kesukaran, dan daya pembeda soal. Uji analisis data yang digunakan dalam penelitian ini yaitu menggunakan uji-t dengan taraf signifikan $5 \%$ dan derajat kebebasan $\left(n_{1}+n_{2}\right)-2$ dan digunakan pula uji $\mathrm{N}$-gain untuk mengetahui peningkatan kemampuan pemecahan masalah per indikator pada kelas eksperimen maupun kelas kontrol.

Penelitian ini dilakukan dengan memberikan perlakuan pada kelas eksperimen berupa model pembelajaran berbasis masalah berbantuan mobile posket book fisika dan perlakuan pada kelas kontrol berupa model pembelajaran berbasis masalah tanpa diberikannya mobile pocket book fisika. Kedua kelas diberikan perlakuan selama tiga kali pertemuan dengan alokasi waktu setiap pertemuan selama 135 menit atau 3 jam pelajaran pada materi momentum, impuls dan tumbukan.

\section{HASIL DAN PEMBAHASAN}

Penelitian ini bertujuan untuk mengetahui pengaruh model pembelajaran berbasis masalah berbantuan mobile posket book fisika terhadap kemampuan pemecahan masalah peserta didik. Penelitian ini merupakan penelitian kuasi eksperimen yang dilakukan dengan memberikan perlakuan berupa model pembelajaran berbasis masalah berbantuan mobile pocket book fisika pada kelas X MIPA 5 sebagai kelas eksperimen dengan jumlah 31 orang dan perlakuan berupa pembelajaran konvensional pada kelas X MIPA 6 sebagai kelas kontrol dengan jumlah 27 orang.

Hasil penelitian yang telah dilakukan berdasarkan tes awal kemampuan pemecahan masalah peserta didik baik pada kelas eksperimen maupun kelas kontrol masih rendah. Hal ini terlihat dari rata-rata tes kemampuan pemecahan masalah pada masing-masing kelas. Nilai rata-rata tes awal yang rendah dikarenakan peserta didik belum diberikan perlakuan dan peserta didik belum memperoleh materi momentum, impuls, dan tumbukan sesuai dengan jenjangnya.

Data hasil tes awal kemampuan pemecahan masalah kedua kelas dianalisis untuk mengetahui homogenitas dan normalitasnya. Untuk mengukur pengaruh perlakuan yang telah diberikan, kedua kelas diberikan tes akhir dengan materi, jumlah, dan bobot soal yang sama seperti diberikannya tes awal. Berdasarkan nilai dan analisis data tes akhir, kelas eksperimen memperoleh nilai rata-rata lebih tinggi yaitu 68,3 dibandingkan dengan nilai rata-rata kelas kontrol yaitu 52,0. Hasil tes awal dan tes akhir kemampuan pemecahan masalah kelas eksperimen dan kelas kontrol dapat dilihat pada Tabel 1 berikut. Tabel 1 menunjukkan bahwa kelas eksperimen dan kontrol memiliki kemampuan yang sama sebelum diberikan perlakuan. Hasil tersebut menunjukkan bahwa peningkatan nilai ratarata di kelas eksperimen lebih tinggi dari peningkatan nilai rata-rata kelas kontrol. Untuk membuktikan lebih lanjut secara statistik maka dilakukan uji hipotesis menggunakan uji-t. Adapun hasil uji hipotesis diperoleh nilai thitung lebih besar dari $t_{\text {tabel }}$ yaitu 5,832 $>2,003$. Hasil ini menunjukkan bahwa model pembelajaran bebasis masalah berbantuan mobile pocket book fisika berpengaruh dalam peningkatan 
kemampuan pemecahan masalah peserta didik.

Tabel 1. Data Hasil Tes Awal dan Tes Akhir Kelas Eksperimen dan Kontrol

\begin{tabular}{ccccccccc}
\hline \multirow{2}{*}{ Tes } & Kelas & $\begin{array}{c}\text { Jumlah } \\
\text { Siswa } \\
(\mathbf{N})\end{array}$ & $\begin{array}{c}\text { Nilai } \\
\text { Max. }\end{array}$ & $\begin{array}{c}\text { Nilai } \\
\text { Min. }\end{array}$ & $\begin{array}{c}\text { Rata- } \\
\text { rata }\end{array}$ & $\mathbf{s}^{2}$ & Varians & Data \\
\multirow{2}{*}{ Awal } & Eksperimen & 31 & 60 & 7 & 28,2 & 14,78 & & \\
\multirow{2}{*}{ Akhir } & Kontrol & 27 & 53 & 7 & 29,0 & 15,30 & Homogen & Normal \\
& Eksperimen & 31 & 83 & 47 & 68,3 & 9,42 & & \\
\hline
\end{tabular}

\section{Kemampuan pemecahan masalah dapat meningkat melalui model} pembelajaran bebasis masalah berbantuan mobile pocket book fisika karena peserta didik dihadapkan langsung pada masalah, sehingga mendorong peserta didik untuk belajar secara aktif atau mandiri, membangun pengetahuan baru, saling bertukar pikiran dengan teman kelompok dan saling membantu dalam menyelesaikan tugas atau LKPD yang disertai bantuan mobile pocket book fisika yang berfungsi untuk memvisualisasikan konsep-konsep abstrak pada materi momentum, impuls, dan tumbukan.

Peningkatan kemampuan pemecahan masalah fisika dapat dilihat dari hasil uji Ngain per indikator. Hasil uji $\mathrm{N}$-gain pada kelas eksperimen menunjukkan nilai yang lebih tinggi dibandingkan dengan kelas kontrol secara keseluruhan. Hasil penelitian ini juga sejalan dengan penelitian sebelumnya oleh Hastuti et al. (2016) yang menyatakan bahwa terdapat perbedaan kemampuan pemecahan masalah fisika yang diajarkan dengan menggunakan model pembelajaran berbasis masalah pada kelas eksperimen dengan kelas kontrol. Selain itu, Hermansyah et al. (2015) dalam penelitiannya menyatakan bahwa media virtual dapat meningkatkan penguasaan konsep dan kemampuan berpikir kreatif peserta didik. Adapun nilai $\mathrm{N}$-gain kelas eksperimen dan kelas kontrol pada tiap indikator disajikan pada Tabel 2 berikut.
Berdasarkan Tabel 2, terlihat persentase peningkatan kemampuan pemecahan masalah lebik baik terjadi pada kelas eksperimen untuk tiap indikatornya. Peningkatan tersebut dikarenakan adaya perbedaan perlakuan, dimana pada kelas eksperimen peserta didik menyelesaikan masalah atau persoalan yang diberikan secara mandiri, serta dengan adanya mobile pocket book fisika dimana materi momentum, impuls, dan tumbukan yang sulit untuk divisualisasikan dapat disampaikan secara mudah dan menarik. Sejalan dengan penelitian ini, Finkelstein dalam Gunawan et al. (2015) menyatakan bahwa perkembangan teknologi computer dapat digunakan untuk membantu meningkatkan pemahaman fisika baik sebagai multimedia interaktif maupun sumber online seperti halnya e-learning.

Indikator-indikator kemampuan pemecahan masalah yang mengalami peningkatan dalam kategori tinggi pada penelitian ini ada tiga, yakni IPM-1, IPM-3, dan IPM-4. Peningkatan tertinggi terjadi pada indikator pemecahan masalah yang pertama yakni pemahaman (understanding) dikarenakan pada indikator tersebut peserta didik memungkinkan untuk memiliki kemampuan memahami ide tau gagasan dalam setiap soal tersebut. Kemudian peningkatan selanjutnya terjadi pada indikator ketiga yakni pembedaan (differentiating) dimana pada indikator ini peserta didik dapat memiliki kemampuan 
membedakan dan memilih penyebabpenyebab yang dapat menghasilkan suatu akibat tertentu. Peningkatan selanjutnya pada indikator keempat yakni penentuan (determining) pada indikator ini peserta didik memiliki kemampuan menentukan konsep, prinsip, teori dan atau hukum fisika yang dapat digunakan untuk mendukung dalam mengidentifikasi sebuah atau beberapa penyebab sehingga menghasilkan suatu akibat.

Tabel 2. Data Hasil Uji N-Gain Kemampuan Pemcahan Masalah Kelas Eksperimen dan Kontrol

\begin{tabular}{ccccccccc}
\hline \multirow{2}{*}{ Kelas } & \multicolumn{9}{c}{ N-Gain per Indikator Kemampuan Pemecahan Masalah } & \multirow{2}{*}{ N-Gain Total } & Kriteria \\
\cline { 2 - 6 } & IPM-1 & IPM-2 & IPM-3 & IPM-4 & IPM-5 & IPM-6 & & \\
\hline Eksperimen & $97 \%$ & $28 \%$ & $92 \%$ & $80 \%$ & $45 \%$ & $20 \%$ & $60 \%$ & Sedang \\
Kontrol & $70 \%$ & $3 \%$ & $54 \%$ & $56 \%$ & $14 \%$ & $6 \%$ & $34 \%$ & \\
\hline
\end{tabular}

Indikator kemampuan pemecahan masalah yang masih tergolong rendah adalah IPM-2, IPM-5, dan IPM-6. Hal ini sejalan dengan penelitian yang dilakukan oleh Amanah et al, (2017) dimana IPM-5 dan IPM-6 masih tergolong rendah karena meski peserta didik telah mampu menemukan masalah dan menemukan ide yang tepat, namun belum dapat menuangkan ide tersebut kedalam solusi yang benar serta belum dapat menentukan dukungan yang relevan dengan ide tersebut. Sedangkan untuk IPM-2 memiliki presentase yang rendah dikarenakan peserta didik masih belum dapat memilih penyebab-penyebab dan memprediksi berbagai kemungkinan pilihan jawaban yang dapat terjadi berkenaan dengan fenomena fisika.

Hasil penelitian belum maksimal dikarenakan beberapa faktor. Faktor pertama adalah model pembelajaran berbasis masalah berbantuan mobile pocket book fisika yang baru diterapkan di sekolah, sehingga peserta didik masih belum terbiasa untuk belajar secara mandiri dan lebih aktif dalam pembelajaran.

\section{PENUTUP}

Pada taraf signifikan 5\% terdapat pengaruh model pembelajaran bebasis masalah berbantuan mobile pocket book fisika berpengaruh dalam peningkatan kemampuan pemecahan masalah peserta didik. Uji N-gain yang dilakukan didapatkan bahwa kelas eksperimen dan kelas kontrol mengalami peningkatan pada kemampuan pemecahan masalah per indikatornya, tetapi kelas ekperimen memiliki peningkatan yang lebih tinggi dibandingkan dengan kelas kontrol.

Model pembelajaran berbasis masalah berbantuan mobile pocket book fisika ini dapat diterapkan untuk meningkatkan kemampuan pemecahan masalah fisika peserta didik dengan memperhatikan beberapa hal, yakni pengaturan alokasi waktu dilakukan sebaik mungkin agar setiap tahap pembelajaran dapat berlangsung secara maksimal. Selain itu sebelum pembelajaran dilaksanakan, media harus dipastikan terinstal dengan baik pada smartphone masing-masing peserta didik sehingga tidak mengurangi waktu selama proses pembelajaran. Suasana kelas yang kondusif juga berperan aktif dalam menstimulus kreativitas peserta didik.

\section{REFERENSI}

Amanah, P. D., Harjono, A., \& Gunada, I. W. (2017). Kemampuan Pemecahan Masalah Dalam Fisika Dengan Pembelajaran Generatif Berbantuan Scaffolding dan Advance Organizer. Jurnal Pendidikan Fisika dan Teknologi, 3(1), 84-91. 
Abdani, R. 2018. Pengaruh Pendekatan Berpikir Kausalitik Ber-Scaffolding dengan Pemberian Tugas Pendahuluan Terhadap Kemampuan Pemecahan Masalah Impuls Dan Momentum Peserta Didik Kelas X (Doctoral dissertation, Universitas Mataram).

Aziz, A., Rokhmat, J., \& Kosim, K. 2017. Pengaruh Model Pembelajaran Berbasis Masalah dengan Metode Eksperimen Terhadap Hasil Belajar Fisika Siswa Kelas X SMAN 1 Gunungsari Kabupaten Lombok Barat Tahun Pelajaran 2014/2015. Jurnal Pendidikan Fisika dan Teknologi, 1(3), 200-204.

Embong, A. M., Noor, A. M., Hashim, H. M., Ali, R. M., \& Shaari, Z. H. (2012). E-Books as Textbooks in the Classroom. Procedia-Social and Behavioral Sciences, 47, 1802-1809.

Gunawan, G. 2017. Keterampilan Berpikir dalam Pembelajaran Sains. Mataram: Arga Puji Press.

Gunawan, G., Harjono, A., \& Sutrio, S. (2017). Multimedia Interaktif dalam Pembelajaran Konsep Listrik bagi Calon Guru. Jurnal Pendidikan Fisika dan Teknologi, 1(1), 9-14.

Hastuti, A., Sahidu, H., \& Gunawan, G. (2017). Pengaruh Model PBL Berbantuan Media Virtual Tehadap Kemampuan Pemecahan Masalah Fisika. Jurnal Pendidikan Fisika dan Teknologi, 2(3), 129-135.

Hermansyah, H., Gunawan, G., \& Herayanti, L. (2017). Pengaruh penggunaan laboratorium virtual terhadap penguasaan konsep dan kemampuan berpikir kreatif siswa pada materi getaran dan gelombang. Jurnal Pendidikan Fisika dan Teknologi, 1(2), 97-102.

Khumaidi, A., \& Sucahyo, I. 2018. Pengembangan Mobile Pocket Book Fisika Sebagai Media Pembelajaran Berbasis Android pada Materi Momentum Dan Impuls. Inovasi Pendidikan Fisika, 7(2).
Landau, R. H., Paez, M. J., Bordeianu, C., \& Haerer, S. 2011. Making physics education more relevant and accessible via computation and eTextBooks. Computer Physics Communications, 182(9), 2071-2075.

Niami, K., Kosim, K., \& Gunawan, G. 2018. Model Problem Based Learning Berbantuan Simulasi Komputer Untuk Meningkatkan Penguasaan Konsep Pada Materi Alat-Alat Optik. Jurnal Pendidikan Fisika dan Teknologi, 4(2), 220-225.

Ngalimun. 2014. Strategi dan Model Pembelajaran. Yogyakarta: Aswaja Pessindo.

Rokhmat, J. 2013. Peningkatan Kemampuan Pemecahan Masalah Mahasiswa Calon Guru Fisika melalui Berpikir Kausalitas dan Analitik. Disertasi. Universitas Pendidikan Indonesia: tidak diterbitkan.

Rokhmat, J., Rusdiana, D., Setiawan, A.. 2012. Pembelajaran Fisika Berbasis Proses Berpikir Kausalitas Dan Berpikir Analitik (PBK-BA), Suatu Pembiasaan Berpikir Secara Terbuka. Seminar Nasional IX Pendidikan Biologi FKIP UNS.

Saavedra, A. R. and Opfer, V. D. 2012. Teaching and Learning $21^{\text {st }}$ Century Skills (Global Cities Education Network Report (Asia Society)). Hongkong: RAND Coorporation.

Seng Tan, O. 2009. Problem Based Learning and Creativity. Singapore: Cengage Learnig Asia Pte Ltd.

Tamami, F., Rokhmat, J., \& Gunada, I. W. 2017. Pengaruh Pendekatan Berpikir Kausalitik Scaffolding Tipe 2a Modifikasi Berbantuan LKS Terhadap Kemampuan Pemecahan Masalah Optik Geometri Dan Kreativitas Siswa Kelas XI SMAN 1 Mataram. Jurnal Pendidikan Fisika dan Teknologi, 3(1), 76-83. 